\title{
Ontogenesis of the Form Biota orientalis compacta (Cupressaceae) in the Conditions of Introduction of the Tashkent Botanical Garden (Uzbekistan)
}

\author{
Eldor E. Temirov ${ }^{1}$, Tashkhanim T. Rakhimova ${ }^{2}$ \\ ${ }^{1}$ Laboratory of Anatomy and Cytoembryology of the Tashkent Botanical Garden Named after Academician F.N. Rusanov, \\ Institute of Botany of the Academy of Sciences, Tashkent, Uzbekistan \\ ${ }^{2}$ Laboratory of Geobatany and Ecology of the Institute of Botany of the Academy of Sciences, Tashkent, Uzbekistan \\ Email: guljon.duschanova@mail.ru
}

How to cite this paper: Temirov, E.E. and Rakhimova, T.T. (2019) Ontogenesis of the Form Biota orientalis compacta (Cupressaceae) in the Conditions of Introduction of the Tashkent Botanical Garden (Uzbekistan). American Journal of Plant Sciences, 10, 1239-1247.

https://doi.org/10.4236/ajps.2019.107089

Received: June 12, 2019

Accepted: July 28, 2019

Published: July 31, 2019

Copyright $\odot 2019$ by author(s) and Scientific Research Publishing Inc. This work is licensed under the Creative Commons Attribution International License (CC BY 4.0).

http://creativecommons.org/licenses/by/4.0/

\begin{abstract}
The ontogenesis of the form Biota orientalis compacta (Cupressaceae) was first studied in the conditions of introduction of the Tashkent Botanical Garden. The passage of periods and stages of ontogenesis, full ripening of the cones, a high rate of growth and development, as well as high seed productivity are the main indicators of the success and prospects of the introduction of the form Biota orientalis compacta. The data obtained will serve as a theoretical basis for the agrotechnical development in landscaping.
\end{abstract}

\section{Keywords}

Ontogenesis, Biota orientalis compacta, Introduction,

Tashkent Botanical Garden, Uzbekistan

\section{Introduction}

Now special attention is being paid to the systematic development of the ornamental, rare and endangered species of plants in the world, their use in ecology, introduction and use in green planting. It should be noted that some of the species and forms of the Cupressaceae family, which are widely used in the field of construction, landscaping, construction industry, are of particular importance.

Studying their ontogenesis in the development of ways to identify these bioaccumulative bioecologic features in terms of introductory conditions, justification of growth and climate change, introduction, and collection of ex-situ condi- 
tions, has a significant scientific and practical significance.

There are twenty-three species of the thirteen species of the Cupressaceae family on earth [1]. In some literature, 142 species of 27 species are widely spread across the southern and northern latitudes of the earth, the second largest family after the Pinaceae family [2]-[8].

Biota orientalis forms of the Cupressaceae family are: Biota orientalis Endl. $\mathrm{f}$. aurea (Dauvesse) Hornibr, Biota orientalis Endl. f. compacta Ungeri Beissn., Biota orientalis Endl. f. justinka Ungeri Beissn., Biota orientalis Endl. f. morgan Ungeri Beissn. which is widely used in landscaping. There are 51 species and forms of 7 species from the Cupressaceae family, introduced in the Tashkent Botanical Gardens. At the same time, we are carrying out scientific research on the reproduction, reproduction, introduction, growth and development of oncogenesis of 21 species and 10 species of 5 species from the Cupressaceae family in the Botanical Garden [9].

Ontogenesis is the individual development of an individual from the moment of fertilization of the egg to the natural death of the organism [10]. R.E. Levin [11] defines ontogenesis as genetically determined stages of development of an individual from the diaspora to extinction. In the individual development of each individual, its genetic program is embodied [12]. Ontogenetic or age-related changes include all aspects of development: metabolic processes, organogenesis, reproduction, aging or rejuvenation.

\section{Materials and Methods}

Biota orientalis compacta-is a perennial decorative form, isolated from the genus Biota L. Ontogenesis Biota orientalis compacta was studied in terms of the introduction of the coniferous plants collection of the Tashkent Botanical Garden. Studies were conducted in 2010-2018.

The Tashkent Botanical Garden is geographically located in the north-eastern part of Tashkent in the basin of the Chirchik belt at an altitude of $440.4 \mathrm{~m}$ above sea level $41^{\circ} 20.847^{\prime} \mathrm{N} 69^{\circ} 19.216^{\prime} \mathrm{E}$. The climate is sharply continental. The average annual temperature is $13.8^{\circ} \mathrm{C}$, the average annual precipitation is $330.3 \mathrm{~mm}$, and the average annual relative air's humidity is $55.6 \%$. Precipitation falls mainly in the autumn-winter and spring periods; soils of cultivated and irrigated gray soils or irrigated soils of desert and desert-steppe areas (gray soils) [13].

On the basis of ontogenesis, there are several patterns of periodization of the individual development of the form Biota orientalis compacta [14] [15], when describing the ontogenesis of Biota orientalis compacta used the method of A.A. Uranov [16]. However, O.I. Evstigneev divided immature and virginal ontogenetic groups into two subgroups- $\mathrm{im}_{1}$ and $\mathrm{im}_{2}, \mathrm{v}_{1}$ and $\mathrm{v}_{2}$. They differ in the rates of growth and increase of the main axis and side auxiblasts. We used the periodization scheme of T.A. Rabotnov [17] and A.A. Uranov [16] [18], also Ontogenetic Atlas of Plants L.A. Zhukova [19]. According to these authors, coniferous plants have 4 periods and 9 age states (stages) of ontogenesis, which we ad- 
here to in our description. Based on the specific development of the form Biota orientalis compacta, age conditions were determined according to the following criteria: I period of primary dormancy (latent)—dormant seeds, II virginal period: $\mathrm{p}$-seedling stage, plant with cotyledons, before deployment of 1 leaf; j-juvenile plant with leaves; im-immature plant with shoots of II order; $\mathrm{v}$-adult vegetative plant; Generation III period-the formation of cones and fruiting plants, IV postgenerative period-subsenile and senile.

\subsection{Latent Period}

In the latent period, the plant is in a state of primary rest in the form of a seed. Biota orientalis compacta seeds are large, grayish, with a length of $0.5-0.6 \mathrm{~mm}$ and a width of $0.2-0.3 \mathrm{~mm}$. The average weight of 1000 seeds is 29.6 grams at the temperature of 4 different temperatures $\left(20^{\circ} \mathrm{C}-22^{\circ} \mathrm{C}, 25^{\circ} \mathrm{C}-26^{\circ} \mathrm{C}, 27^{\circ} \mathrm{C}\right.$ $28^{\circ} \mathrm{C}, 30^{\circ} \mathrm{C}-32^{\circ} \mathrm{C}$ ) to the thermostat to determine the susceptibility of the seeds in the laboratory. The favorable temperature of the seeds in laboratory conditions is $+20^{\circ} \mathrm{C}+22^{\circ} \mathrm{C}$ where the seeds are $17 \%$ in 6 days and $78 \%$ in 15 days. Temperature at $+25^{\circ} \mathrm{C}+26^{\circ} \mathrm{C}$ was $46 \%$, and $+27^{\circ} \mathrm{C}+28^{\circ} \mathrm{C}-7 \%$. The highest temperature in the experiments $\left(+30^{\circ} \mathrm{C}+32^{\circ} \mathrm{C}\right)$ was $3 \%$. The mean values of the three samples taken from the seeds at different temperatures are shown in Figure 1.

\subsection{The Virginal Period Is the Sprout Stage}

The study of seedlings is an important point in the knowledge of plant ontogenesis. The seedling is the most mesomorphic and easily vulnerable stage of ontogenesis, which determines the existence of the species. The study of the first assimilating organs contributes to the clarification of their adaptive level and kinship coniferous.

\subsection{The Grass Stage}

In this stage, the seeds are divided into two opposite lancets and have a soft, dark

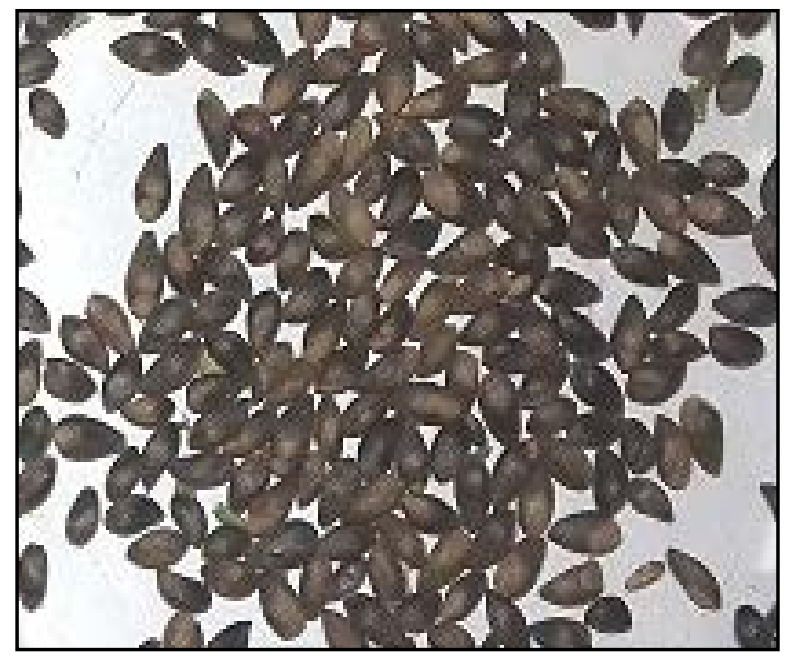

Figure 1. The latent period of the ontogenesis of the form Biota orientalis compacta. 
green length of $2.3-3.2 \mathrm{~cm}$ and a width of $0.2-0.3 \mathrm{~mm}$. The length of hippocotyledgia is $4.1-6.2 \mathrm{~cm}$, and the root is $0.8-1.3 \mathrm{~cm}$, and the brown, unstucked, diameter of the root canal has reached $1 \mathrm{~mm}$ (Figure 2).

\subsection{Juvenile Stage}

The plants have an unbranched shoot of the first order, $7-9$ (15) $\mathrm{cm}$ high, with juvenile leaves with cotyledons. The first true leaves are needle-shaped opposite, located directly above the cotyledons, $1.6-2.2 \mathrm{~cm}$ long, $0.8-1 \mathrm{~mm}$ wide, hard, spinous at the top (prickly), glaucous at the top and bright green on the underside, with clearly pronounced median vein. The leaves are located first oppositely, and later in whorls of four. They are similar in appearance to the needles of the previous ontogenetic state. Stem rough light brown color. The root system is rod, lateral roots are formed.

\subsection{Immature Stage}

For vegetatively renewing individuals, a creeping shape of shoots was observed, which is formed as a result of lodging of the lower rooted branches of the genet and ramet. Therefore, the base of the trunk is often with a characteristic bend visible above the soil surface. Lateral roots are few. The needles of juvenile (needle-shaped) and adult (linear-lanceolate) types, up to $20-25 \mathrm{~mm}$ long and up to $1.5 \mathrm{~mm}$ wide (Figure 3, Figure 4).

The real fir-needles. At the end of July (30.07), the height of the plant was 10 $15 \mathrm{~cm}$, and from that moment the actual budgets began to form. In one round, 3 - 4 real boulders were formed (side branches). At the end of September (26.09.18 y.), the rods in this case were green. The number of 1-sideways formed on the

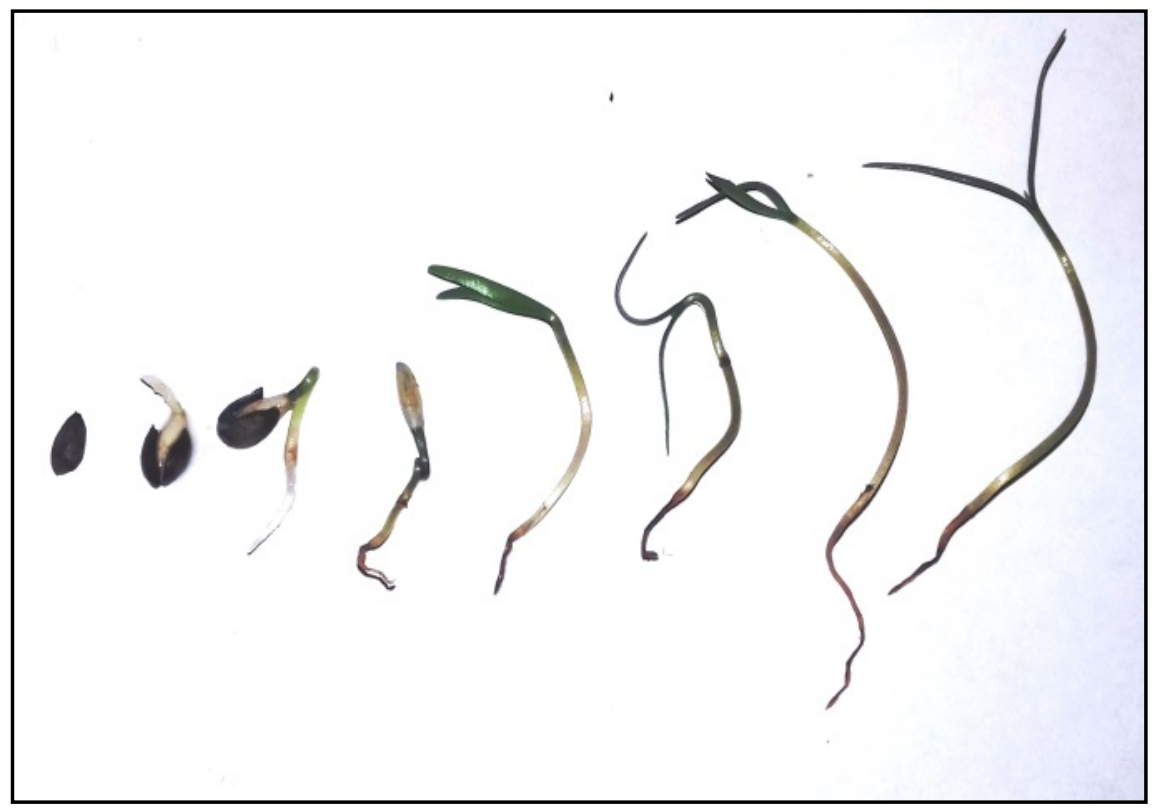

Figure 2. The virginal period is the seedling stage of the ontogenesis of the form Biota orientalis compacta. 

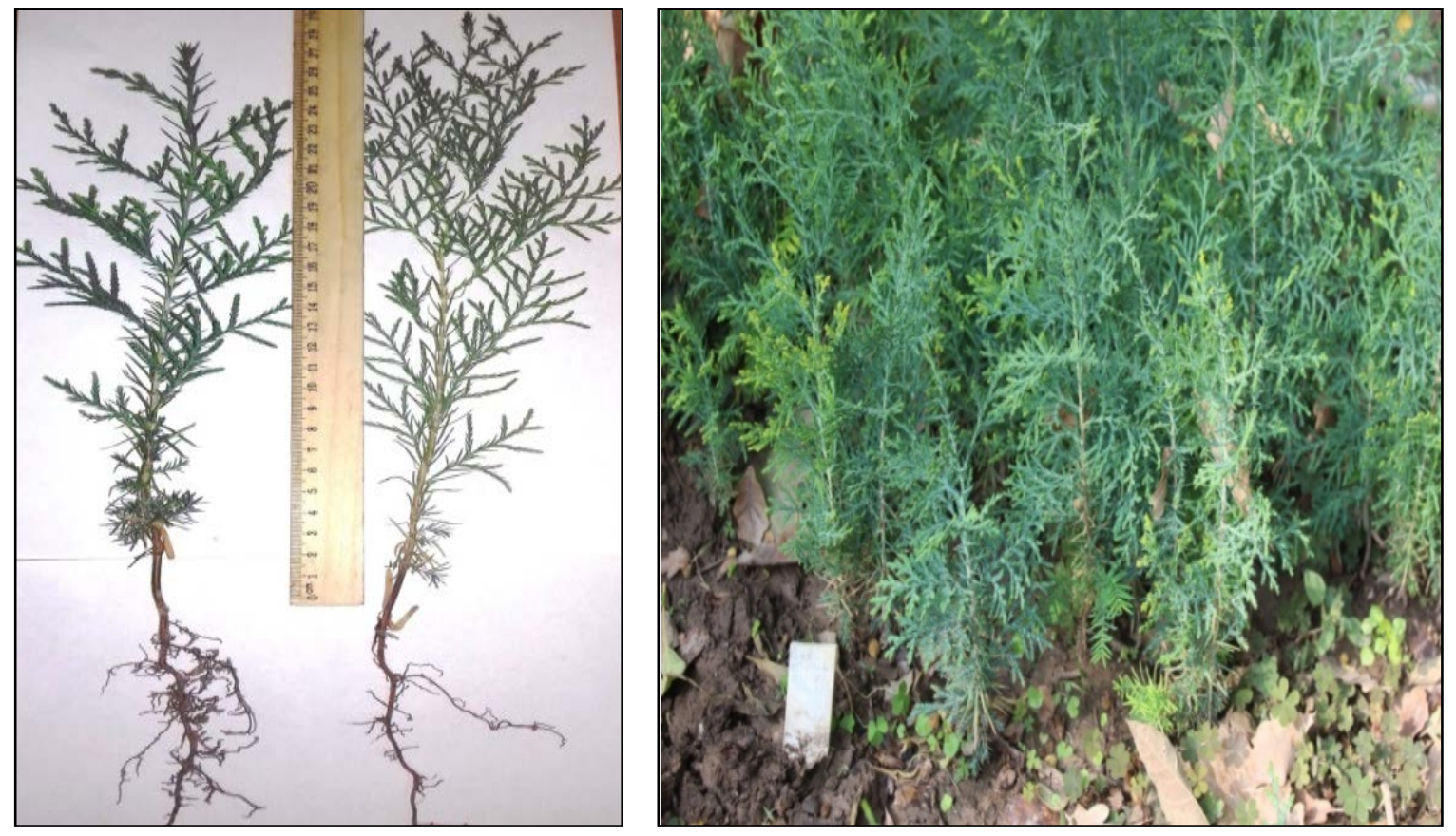

Figure 3. The immature stage (im) of the form of Biota orientalis compacta.

actual rods has increased to $8-10$. Their length is $4-8 \mathrm{~cm}$. The stem is brown, with a diameter of up to $0.6 \mathrm{~cm}$. The root system is rod with lateral roots up to IV order. Individuals with shoots II-III orders of branching and a height of 30 $50 \mathrm{~cm}$.

\subsection{Virginal Stage}

Plants with features of an adult plant, a developed shoot system and not yet started seed production. They have well-developed stem and crown, and the maximum increase in height for the whole ontogenesis. The magnitude of the current growth of the trunk in length is much higher than those of large branches, which determines the elongated shape of the crown with a pointed apex. The diameter of the trunk exceeds the diameter of the skeletal branches 3 times or more. The escape system consists of branches $4-5$ orders of magnitude. The trunk is covered with periderm (the cortex is usually not developed yet). The root system includes the main root, lateral roots of different orders and adventitious roots. The height of the plant is $60-70 \mathrm{~cm}$, the root diameter has reached $0.8-1 \mathrm{~cm}$. There are $10-12$ horns in a single bush with a length of $15-30$ $\mathrm{cm}$, a medium $26-36 \mathrm{~cm}$ long and a top $12-13 \mathrm{~cm}$ in length. There are 4 branch horns, the $3-4$ order is a rod that is generated this year. The main root length was $30-35 \mathrm{~cm}, 2$-fold $20-25 \mathrm{~cm}, 3$-fold $12-14 \mathrm{~cm}$ and 4 -fold $4-6 \mathrm{~cm}$. It was found that there are 3 rows of roots. At the beginning of their development, virginal trees are in the tier of shrubs, at the end they enter the tree tier (Figure 4).

\subsection{Generative Period}

The young generative stage of a plant $\left(\mathrm{g}_{1}\right)$ is multi-stemmed, less often sin- 
gle-stemmed trees or shrubs and start seed production for the first time. Seed organs are localized in the upper part of the crown, there are few seeds. The growth of the trunk in height is intense, the order of branching reaches $4-5$ and more. There is a drying of the lower branches and the formation of a crust at the base of the trunk (Figure 4, Figure 5).

The roots are brown with thick periderm. The branching of the root system reaches VI order. Generative organs are located in the upper part of the crown.
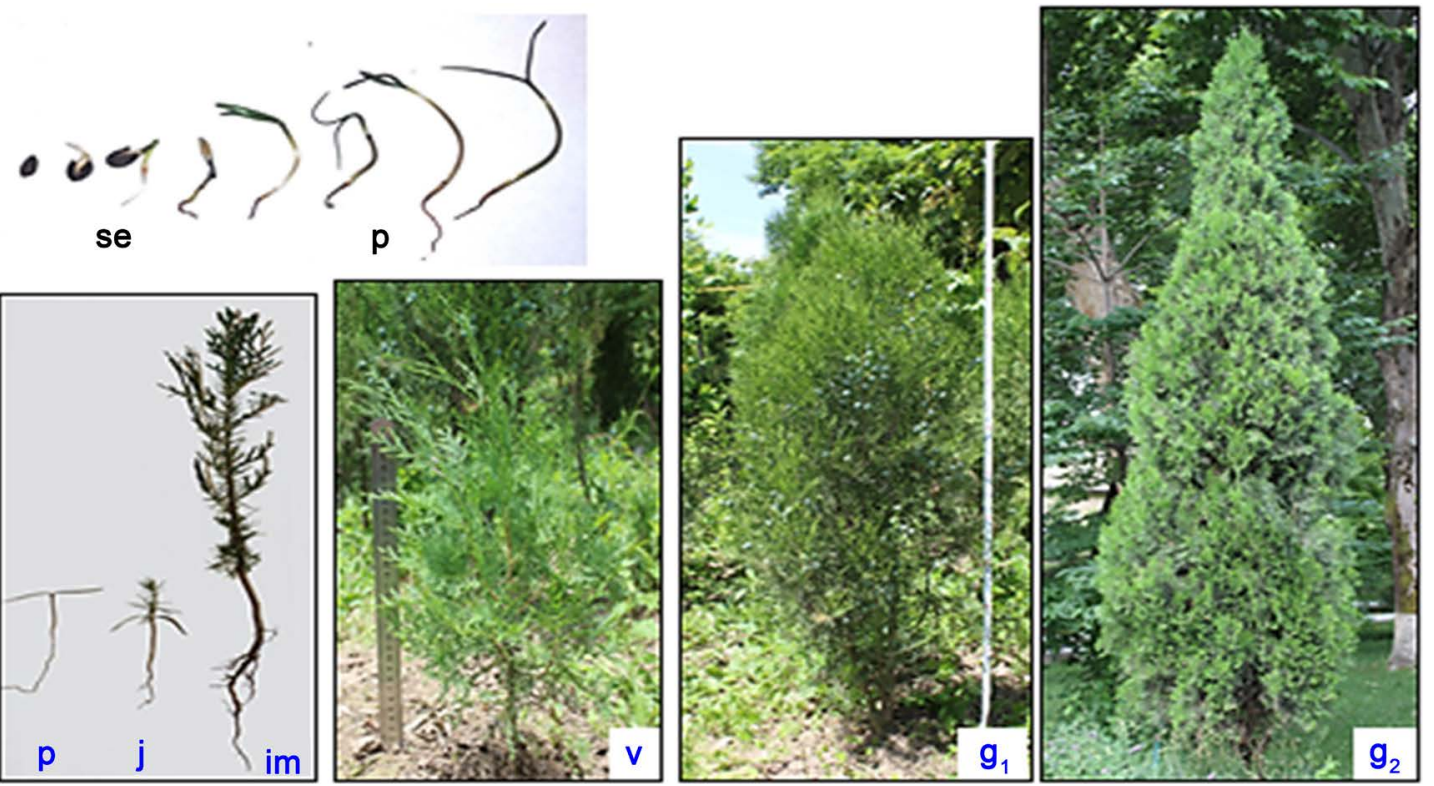

Figure 4. Periods and stages of ontogenesis of the form of Biota orientalis compacta.
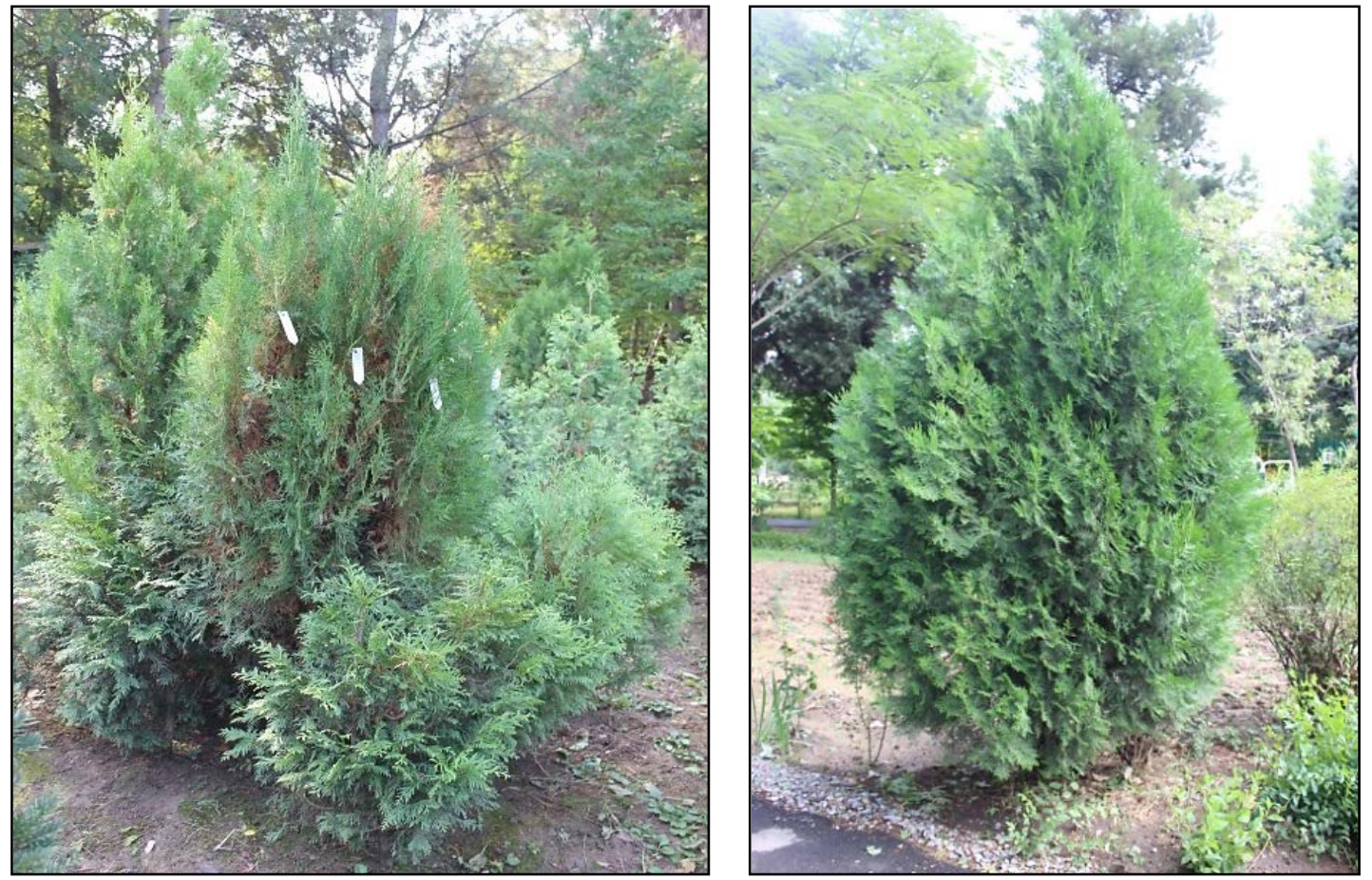

Figure 5. Young generative stage of the form Biota orientalis compacta. 
In this form, fewer mother flowers and pollen have been observed since the $5^{\text {th }}$ to $6^{\text {th }}$ centuries. In the five-year-old tree, about 10 cones formed. The five-year-old Biota orientalis compacta form has a height of $90-110 \mathrm{~cm}$ at the end of the growing season. The number of horns that came from the main stem was 16 . The first primary body is $110 \mathrm{~cm}$. The second horn is $15-20 \mathrm{~cm}$ in the lower part of the body, $36-40 \mathrm{~cm}$ in the middle and $12-14 \mathrm{~cm}$ in the upper part, and the third is a new branch, with a length of $6-13 \mathrm{~cm}$. According to our observations, the height of the 10-year-old Biota orientalis compacta at the end of the growing season in 2018 has reached 1-2 m. This depends on the plant's habitat. The circle of horns in the middle of the body is $40 \times 40,50 \times 50,60 \times 60 \mathrm{~cm}$. The diameter of the rib cage is $2-3 \mathrm{~cm}$. The condition of the plant is good, the disease is not recorded.

It was found that $50 \%-60 \%$ of the ripening cones in the plant. The formation of the cones is dated to $2-3$ decades of August, and will be ripen in September of next year. The length of the cone is $1.7-2 \mathrm{~cm}$ and its width is $1.5-1.7 \mathrm{~cm}$. There are $4-6$ seeds in one cone. The number of cones in a single bush has been reduced to 12 - 52. Some cones do not have cones. It is estimated that $90 \%$ of the decade-old seedlings have been harvested.

\subsection{The Average Generative Stage of the Plant $\left(\mathrm{g}_{2}\right)$}

In the middle of the generative stage, individuals are powerful plants, characterized by the maximum number of cones localized in the upper and middle parts of the crown. The roots are light brown or brown. Lower shoots are bare; in the branch of horizontal plane, there is their active rooting. Often there is a drying up of the branches and needles of not only the lower, but also the middle part of the crown. Crust covers the trunk almost to the middle.

The 20-year-old Biota orientalis compacta form on the collection area has a height of $4-5$ meters. The diameter of the horns in the middle is $4-5 \mathrm{~m}$. There are about 300 to 400 cones in a tiny mother's tree. The diameter of the main body root collar is $12-14 \mathrm{~cm}$. Biota orientalis compacta is a biologically sunny plant that grows well in open spaces. The middle-aged generation stage was significantly different from the younger generation and the height of the tree. Average annual growth rates in the middle-aged trees are $14-16 \mathrm{~cm}$ in the middle of the tree, $20-22 \mathrm{~cm}$ in the upper and $6-8 \mathrm{~cm}$ at the bottom. The number of longitudinal horns from the main body is about 20 to 30 , the length of which is 2 $-2.2 \mathrm{~m}$ in the lower part of the body. At this stage, the formation of one of the variants of the life form is completed: a multi-stem and rarely a single-stem tree or shrub.

We did not carry out the old generative $\left(\mathrm{g}_{3}\right)$ and subsenile and senile (s) stages of the form of Biota orientalis compacta, since we do not have old generative individuals and subsenile and senile plants.

According to the literature Zhukova L.A., Notov A.A., Turmukhametova N.V. et al. [19], in ontogenesis the species Pinus sylvestris L. old generative plants, in 
connection with the cessation of growth in height, have a flat top of the crown. The increments of the lateral branches are insignificant. Trees reach maximum height. Trees can sometimes become two-, three-, rarely multi-stemmed, individual trunks often die off, sometimes collapse, forming stumps. Many large leading branches also die. Young branches in the apex of the crown gains are minimal. Needles function 2 years. Trunks all over covered with a rough fissured crust. Subsenile plants, as a rule, have stumps or their collapsing remnants, sometimes with a preserved dead small trunk. Separate areas with live depressed brachyblasts with small needles can remain on the trunk. Senile and dying developmental states are practically not found. They are sometimes mistaken for dying, strongly depressed instances of impaired vitality, which fall out of being in other developmental states. In contrast, senile and dying individuals have common dimensional characteristics comparable to middle-aged and old generative plants [19].

A comparative study of the ontogenesis of Biota orientalis compacta and $P$. sylvestris revealed the following similar and distinctive features. Biota orientalis compacta seeds are dark brown, with a length of $0.5-0.6 \mathrm{~mm}$ and a width of 0.2 - $0.3 \mathrm{~mm}$. The average weight of 1000 seeds is 29.6 grams, which is 3 times heavier than Pinus sylvestris. In P. sylvestris, the seeds are supplied with wings $12-18 \mathrm{~mm}$ long. Seeds are gray-brown, often with dark stripes. The weight of 1000 seeds is 3.6 - 10.3 g. Cotyledon leaves Biota orientalis compacta as in P. sylvestris species persists for up to 2 years, while they turn yellow and begin to dry out [15].

Juvenile plants Biota orientalis compacta, as in the species P. sylvestris, has a first-order, unbranched shoot. The first true leaves are acicular, opposite, located directly above the cotyledons. The height of the virginal plant $P$. sylvestris reaches from 3 to $10 \mathrm{~m}$ [20]. The height Biota orientalis compacta reaches 60 $70 \mathrm{~cm}$ and is considered undersized compared to P. sylvestris.

Thus, the ontogenesis of the form of Biota orientalis compacta (Cupressaceae) was first studied in the conditions of introduction of the Tashkent Botanical Garden. The ontogenesis of the form Biota orientalis compacta is described in the Tashkent Botanical Garden. The passage of periods and stages of ontogenesis, full ripening of the cones, a high rate of growth and development, as well as high seed productivity are the main indicators of the success and prospects of the introduction of the form Biota orientalis compacta. The data obtained will serve as a theoretical basis for the agrotechnical development in landscaping.

\section{Conflicts of Interest}

The authors declare no conflicts of interest regarding the publication of this paper.

\section{References}

[1] Mischa, O. (2013) Cupressaceae the Cypress Family. Spring, Berlin, 22-30. 
https://doi.org/10.1515/9781400851850.30

[2] Kotov, M.M. and Gruzdeva, L.I. (1995) A Variety of Coniferous Woody Plants for Resistance to Dehydration of Needles. Proceedings Report, Yoshkar-Ola, 80-87.

[3] Lantratova, A.S. (1980) Coniferous Plants. Karelia, Petrozavodsk, 95-98.

[4] Markovskiy, Yu.B. (2006) All Conifers. Fiton, Moscow, 272.

[5] Gordienko, I.I. (1971) Trees and Shrubs. Gymnospermae: Reference Book. Science, Dumka, 156.

[6] Senkina, S.N. (2002) Ecological and Physiological Characteristics of Transpiration of Coniferous Trees in the Phytocenoses of the North. Ecology, 4, 254-260.

[7] Suchkov, G.A. (2002) Resistance of Coniferous Trees in Conditions of Technogenic Pollution of the City of Voronezh: Author's Abstract. Bottom. PhD Voronezh, 23.

[8] Gerasimov, A.O. (2003) Resistance of Conifers in Street Plantings of St. Petersburg: Gerasimov. St. Petersburg, 181.

[9] Temirov, E. and Rakhimova, T. (2018) The Current State of the Introduced Species and Forms of the Cypress Family (Cupressaceae F.W. Neger) under Conditions of the Tashkent Botanical Garden Named after Acad. F.N. Rusanova. Uzbekistan Biological Journal, 5, 48-50.

[10] Kondratieva-Melville, E.A. (1979) Development of the Structure in the Ontogenesis of an Annual Dicotyledonous Plant. Leningrad State University, Leningrad, 116.

[11] Levina, R.E. (1981) Reproductive Biology of Seed Plants. Science, Moscow, 96.

[12] Zhukova, L.A. (1988) Some Aspects of Studying the Ontogenesis of Seed Plants. In: Issues of Ontogenesis of Plants, MarSU, Yoshkar-Ola, 3-14.

[13] Duschanova, G.M. (2016) Adaptive Features of Vegetative Organs of Species of the Genus Climacoptera Botsch. Thesis of Doctor of Biological Sciences, Tashkent, $35-36$.

[14] Serebryakov, I.G. (1962) Ecological Morphology of Plants. Life Forms of Angiosperms and Conifers. Higher School, Moscow, 378.

[15] Evstigneev, O.I. and Tatarenkova, N.A. (1995) Ontogenesis of Scots Pine in Different Ecological Conditions of the Nerusso-Desnyansky Polesye. Nerussa, 48.

[16] Uranov, A.A. (1967) Ontogenesis and Age Composition of Flowering Plant Populations. Science, Moscow, 3-8.

[17] Rabotnov, T.A. (1950) Life Cycle of Perennial Herbaceous Plants in Meadow Cenoses. Tr. BIN Academy of Sciences of the USSR. Geobotany. Moscow. USSR Academy of Sciences, 3, 7-204.

[18] Uranov, A.A. (1975) Phytopopulation Age Spectrum as a Function of Time of Energy Wave Processes. Biological Sciences, 2, 7-34.

[19] Zhukova, L.A., Notov, A.A., Turmukhametova, N.V. and Teterin, I.S. (2013) Ontogenesis of Scots Pine (Pinus sylvestris L.). Ontogenetic Atlas of Plants. Yoshkar-Ola, 26-66.

[20] Pchelin, V.I. (2007) Dendrology. MarSTU, Yoshkar-Ola, 519. 